\title{
Reinstatement of Leuctra biellensis Festa, 1942 (Plecoptera, Leuctridae)
}

\author{
Gilles Vinçon ${ }^{1}$, Louis Boumans ${ }^{2}$, Jean-Luc Gattolliat ${ }^{3,4}$ \\ 155 Bd Joseph Vallier, F38100 Grenoble, France \\ 2 Natural History Museum, University of Oslo, P.O. Box 1172 Blindern, 0318 Oslo, Norway \\ 3 Museum of Zoology, Palais de Rumine, 1014 Lausanne, Switzerland \\ 4 Department of Ecology and Evolution, Biophore, University of Lausanne, 1015 Lausanne, Switzerland \\ http://zoobank.org/F323D418-854C-4068-B4DD-90E33F542BFF
}

Corresponding author: Gilles Vinçon (gvincon@gmail.com)

Received 15 December 2017

Accepted 10 March 2018

Published 3 May 2018

Academic editor:

Dávid Murányi

\section{Key Words}

\section{Stoneflies}

Switzerland

Italy

Alps

Leuctra nigra

neotype

\begin{abstract}
Both molecular and morphologic characters support the reinstatement of Leuctra biellensis Festa, 1942 as a valid species distinct from Leuctra nigra (Olivier, 1811). Genetic distances between L. biellensis and the different populations of L. nigra are around 9\%, while intraspecific distances among $L$. nigra haploclades are less than $1 \%$. Morphologically, the two species can be separated in male adult specimens by the shape of the two teeth on tergite VIII, by the lateral edges of tergites and by the distal expansion of the paraprocts. Leuctra biellensis occurs on the southern slope of the Alps in Italy and Switzerland (Ticino and Graubünden), while L. nigra has a wide distribution in Central and Northern Europe. As the type material of L. biellensis was lost, and to avoid future confusion between the two species, we designate as neotype a male imago collected at the type locality.
\end{abstract}

\section{Introduction}

The SwissBOL (Swiss Barcode of Life) is an ongoing Project, started in 2011, which aims at inventorying the genetic biodiversity of all taxa occurring in Switzerland. Against the background of global warming and other anthropogenic pressures that are threatening freshwater aquatic biodiversity, Ephemeroptera (mayflies), Plecoptera (stoneflies) and Trichoptera (caddisflies) are considered as particularly vulnerable groups (Tierno de Figueroa et al. 2010, Conti et al. 2014, Errochdi et al. 2014). Between 2013 and 2015, DNA barcode sequences were obtained for 90 of the 112 stonefly species reported from Switzerland (Gattolliat et al. 2016). Complementary field searches were done in 2015 and 2016 to elucidate several cases of isolated specimens on the gene tree. First results showed high intraspecific genetic distances between some populations preliminary identified as Leuctra nigra (Olivier, 1811). It was hypothesized that two species were involved, one in the North of the Alps and one in the South (Gattolliat et al. 2016).

Leuctra biellensis Festa, 1942 was originally described from Val Chiobbia in the Piedmont, Northern Italy. This taxon was subsequently considered as a junior synonym of L. nigra by Consiglio (1967). The present reinstatement of $L$. biellensis is based both on genetic evidence and on distinctive morphological characters shared by all the specimens occurring along the southern slope of the Alps. New detailed comparative descriptions are given for L. biellensis and L. nigra.

The original description of Leuctra biellensis was based on a single male imago collected by F. Capra. Type material was reportedly deposited at Museo Civico di Storia Naturale "Giacomo Doria", Genova, Italia 
(Festa 1942). However, we were unable to locate the type. According to the present curator of the entomological collection, it may be lost or may have never been deposited (Maria Tavano, comm. pers. 2015). In order to stabilize the nomenclatural concept of $L$. biellensis and to avoid future confusion between L. biellensis and L. nigra, we designate a neotype for $L$. biellensis, collected as close as possible to the type locality (article 75.3, ICZN 1999). The neotype and some of the topotypes were deposited at the Museo Civico di Storia Naturale "Giacomo Doria", Genova, Italy.

\section{Material and methods}

Molecular study: DNA was extracted from specimens stored in the collection of the Museum of Zoology in Lausanne, using a non-destructive method allowing a posteriori morphological identification. $658 \mathrm{bp}$ of the mitochondrial protein-coding gene cytochrome c oxydase subunit I (CO1) was amplified using the primers LCO1490 and HCO2198 (for details see Gattolliat et al. 2016).

Additional sequences were downloaded from the Barcode of Life Data System (BOLD) database, notably four sequences from Bavaria, projects Barcoding Fauna Bavarica (Hendrich et al. 2010) and Germany Malaise Trap 05 [GMGRC] (Geiger et al. 2016), two Belgian and four Norwegian sequences from the project 'Norwegian Barcoding of Life [NorBOL] - Freshwater Insects' (Boumans and Brittain 2012), and one more Swiss sequence from the project 'West Palaearctic Plecoptera [WPPLE]'. All specimens are listed in Table 1. Sequences of Leuctra hippopus Kempny, 1899 and Leuctra pseudorosinae Aubert, 1954 were added to the data matrix as outgroups, as these have the most similar mitochondrial haplotypes according to Gattolliat et al. (2016).

The final data matrix included 25 COI sequences of 587-658 bp (no gaps or missing data). Analyses were conducted in MEGA7 (Kumar et al. 2016). We used uncorrected $\mathrm{p}$ distances to calculate genetic distances between haplotypes, and within and between major haploclades (Srivathsan and Meier 2012).

Tree topology was reconstructed using the Maximum Likelihood method based on the Tamura-Nei model (Tamura and Nei 1993). The tree with the highest log likelihood is shown. The percentage of trees in which the associated taxa clustered together is shown next to the branches (bootstrap, 1000 replicates).

Morphology: Ethanol-preserved specimens of $L$. nigra and potential L. biellensis from the collections of the Museum of Zoology in Lausanne (MZL), Delmastro (Del), Murányi (Mur), Ravizza (Rav) and Vinçon (Vin) were examined. Since 2016, all of Ravizza's collection is housed in the MZL. Neotype, as well as five male and five female imagoes are deposited at the $\mathrm{Mu}-$ seo Civico di Storia Naturale "Giacomo Doria", Genova, Italy. The full list of examined specimens is given in the results section.

\section{Results}

\section{Molecular study}

The mitochondrial phylogeny clearly recovers L. nigra and L. biellensis as distinct monophyletic clades (bootstrap of $100 \%$ ), with intraspecific distances below $1 \%$ (Table 2). Distances between haplotypes of L. biellensis and haplotypes of L. nigra range from 8.8 to $9.1 \%$, while distances between these species and L. pseudorosinae and L. hippopus, are between 13 and 15\% (Table 2). Distances between populations within L. nigra are always under $1 \%$ even in the case of geographically distant sites such as Finnmark in Norway and Bavaria in Germany (Table 2).

\section{Morphological re-examination and redescription Leuctra nigra (Olivier, 1811)}

Figs 1, 2a-g

Nemoura nigra Olivier 1811: 186

Leuctra acuminata Bengtsson, 1933 (syn. fide Brinck 1949).

Leuctra nigra Oliv., Mosely 1932: 27, figs 39-40, pl. V/26; Kühtreiber 1934: 76, fig. 55; Despax 1951: 140, fig. 61c-d; Illies 1955: 68, fig. 61; Aubert 1959: 65, figs 159-160; Mendl 1968: 70; Kis 1974: 87, 88, figs 37a-e; Ravizza and Vinçon 1998: 303, fig. 6a-f; Teslenko and Zhiltzova 2009, 223, figs 1235-1239; Lubini et al. 2012: 180, fig. 433, 196, fig. 477.

Locus typicus: France, Versailles.

Material examined. FRANCE: BRITANY: Finistère: Rosnoen, Toulencoat, 22.03.2001, $6 \hat{\jmath}$ (Manach leg). VOSGES MASSIF: Vosges: SW Colmar, > Wasserbourg, Krebsbach, Fecht trib., Ill trib., 700 m, 17.05.1995, 10 ${ }^{\AA}$, 13; Ballon d'Alsace, Saut-de-la-Truite, 23.08.1996, $1 \delta^{\jmath}$, $8 \bigcirc$ (Vin). MASSIF-CENTRAL: Saône-et-Loire: Morvan Massif, Haut-Folon, 800 m, 14.07.1994, 5ð̂, 7 우 (Vin); Puy-de-Dôme: Forez Mountains, > Vertolaye, > Chansert Pass, Jasserie de la Croix Fossat, 1500 m, 17.07.1994, $3 \hat{\jmath}$, 7웅 St Pierre-la-Bourlhonne, cross road to the Chansert Pass, Dore trib., 17.07.1994, 19; W. Clermont-Ferrand, between Pontaumur and La-Forêt, b., 21.04.2009, 10̄, 5 우 (Vin). Loire: Mont Pilat, Graix, 900 m, 17.07.1994, 1; Mont Pilat, Crêt de la Perdrix, Gier b., 1400 m, 17.07.1997, $3 \uparrow$ (Vin). Ardèche: Mont Gerbier-de-Jonc, Loire spring, 16.06.2001, 2 ; Lachamp-Rafael, Bois de Cuze, peat bog, 1350 m, 15.06.2001, 4^, 6 ㅇ (Vin). Cantal: Plomb-du-Cantal Massif, > Super Lioran, 1300 m, 30.07.2004, 3 (Vin). Tarn: NW slope of Pic de Nord, Arnette trib., Thoré trib., 850 m, 1.05.1991, 4 $ڤ, 2$ (Vin). Aude: > Citou, spring, trib. of Argent-double, 900 m, 1.07.1989, 1q, 1.05.1991, 20 ${ }^{\lambda}, 3 \propto$ (Vin). JURA MASSIF: Ain: La Vattay Ski Station, Faucille Pass, 1300 m, 30.05.1991, 1ðै, 27.06.1995, 1 ㅇ, 13.07.1996, 1 ㅇ (Vin); Valserine, Combe de Mijoux, Le Planet, 1200 m, 19.07.1991, 3 \%; Valserine, Joux Verte, 19.07.1991, 2 + (MZL); Doubs: Jougne, Swiss Border, Les Tavins, La Tavine, Orbe trib., 900 m, 28.06.1995, 1 q (Vin). ALPS: Haute-Savoie: Montet Pass, > Vallorcine, EauNoire trib., 1450 m, 21.06.1991, 20̂, 15 ㅇ (Vin); Savoie: Allevard, Val Pelouse, 1400 m, 7.06.1987, 10§̊, 1ㅇ; Saisie 


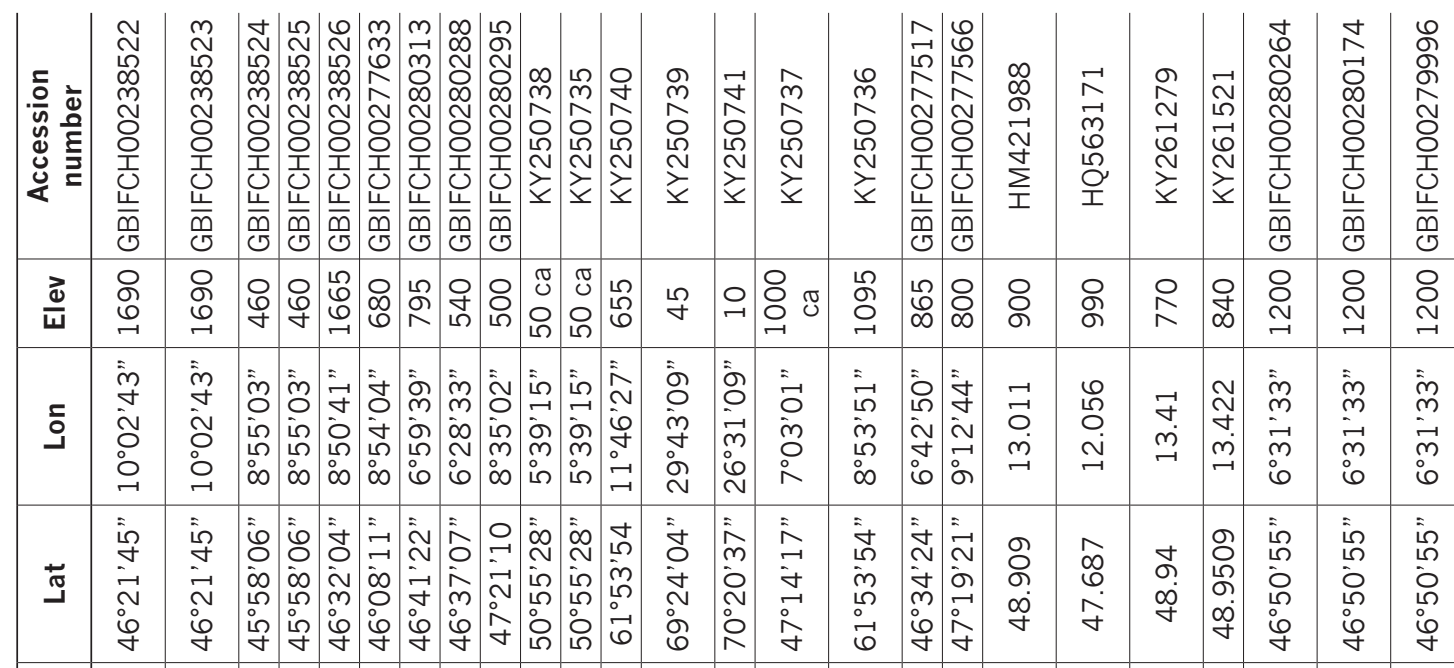

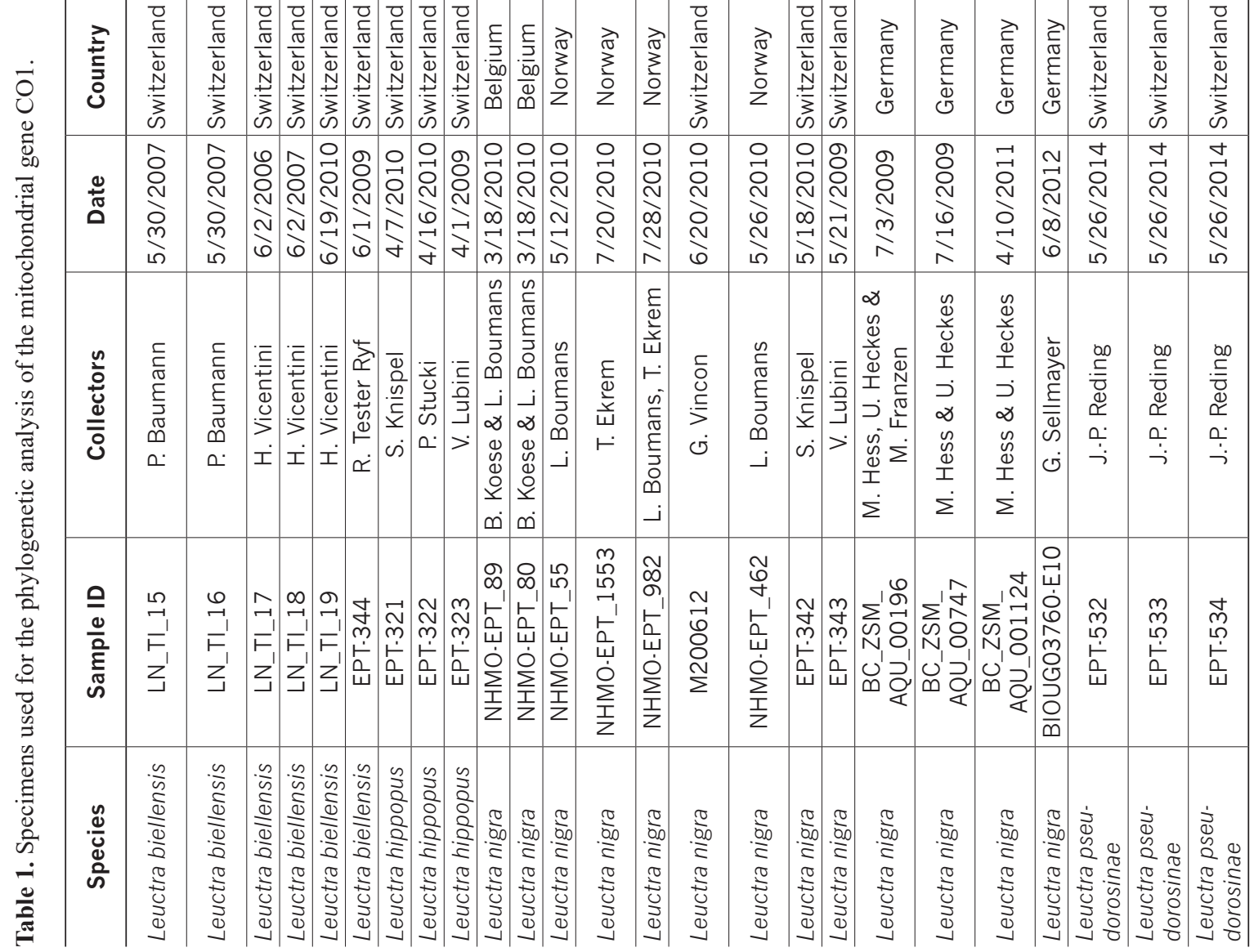


Table 2. Estimates of evolutionary divergence between geographical clusters of Leuctra nigra and Leuctra biellensis using uncorrected $\mathrm{p}$ distances. Minimum and maximum distances are indicated in brackets.

\begin{tabular}{|c|c|c|c|c|c|c|}
\hline & $\begin{array}{c}\text { L. nigra Germany } \\
\text { \& CH }\end{array}$ & L. nigra Norway & L. nigra Belgium & L. biellensis & L. hippopus & L. pseudorosinae \\
\hline \multirow{2}{*}{$\begin{array}{l}\text { L. nigra } \\
\text { Germany \& CH }\end{array}$} & 0.000 & & & & & \\
\hline & $(0.000-0.001)$ & & & & & \\
\hline \multirow{2}{*}{ L. nigra Norway } & 0.007 & 0.001 & & & & \\
\hline & $(0.002-0.010)$ & $(0.000-0.009)$ & & & & \\
\hline \multirow{2}{*}{ L. nigra Belgium } & 0.004 & 0.004 & 0.000 & & & \\
\hline & $(0.000-0.007)$ & $(0.002-0.009)$ & $(0.000)$ & & & \\
\hline \multirow{2}{*}{ L. biellensis } & 0.091 & 0.088 & 0.091 & 0.001 & & \\
\hline & $(0.090-0.094)$ & $(0.085-0.090)$ & $(0.090-0.092)$ & $(0.000-0.002)$ & & \\
\hline \multirow{2}{*}{ L. hippopus } & 0.141 & 0.139 & 0.141 & 0.135 & 0.000 & \\
\hline & $(0.140-0.143)$ & $(0.138-0.140)$ & $(0.141)$ & $(0.135)$ & $(0.000)$ & \\
\hline \multirow{2}{*}{ L. pseudorosinae } & 0.154 & 0.152 & 0.155 & 0.128 & 0.133 & 0.001 \\
\hline & $(0.153-0.157)$ & $(0.152-0.153)$ & $(0.155)$ & $(0.124-0.131)$ & $(0.131-0.136)$ & $(0.000-0.007)$ \\
\hline
\end{tabular}

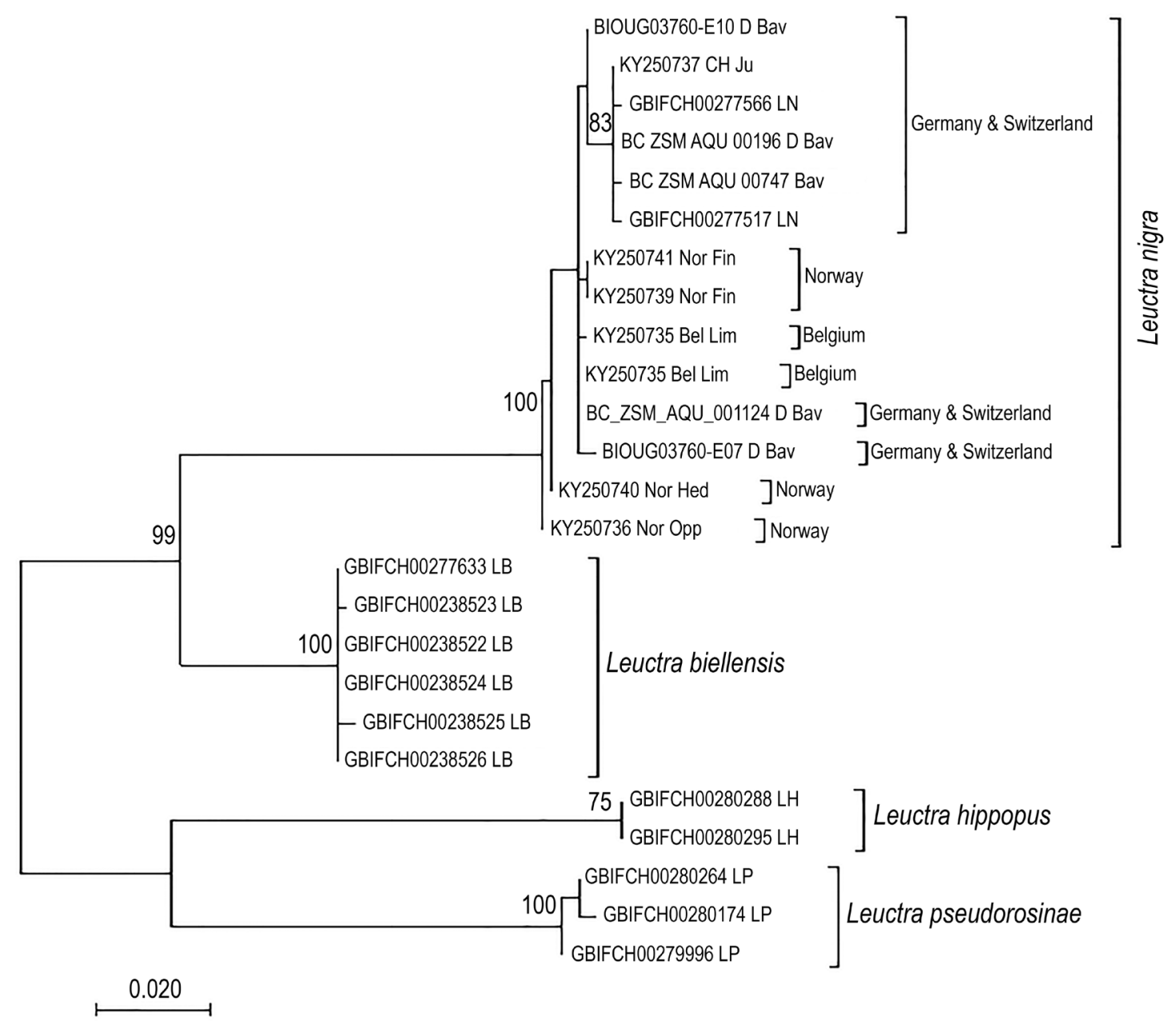

Figure 1. Maximum Likelihood (ML) consensus tree reconstructed for 25 specimens of Leuctra spp. Tree drawn to scale, branch lengths measured in number of substitutions per site, deeper nodes labelled above branches with Maximum Likelihood bootstrap support.

Pass, Nant Rouge trib., 1600 m, 22.05.1991, 1ð̂, 1 ( (Vin). Isère: Chartreuse Massif, < Charmette Pass, Tenaison b.,

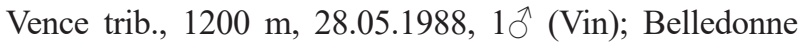
Massif, below Oursière Cascade, Doménon trib., brook,
1500 m, 4.06.1995, 1ठ̄, 1우 < Chamrousse, Fénérieux b., Prémol trib, between Prémol Forest House and Luitel Lake, 1200 m, 10.06.1985, 1ð̂, 3q; < Chamrousse, Premol Forest House, Sonnant trib., 1100 m, 10.06.1985, 1우, 

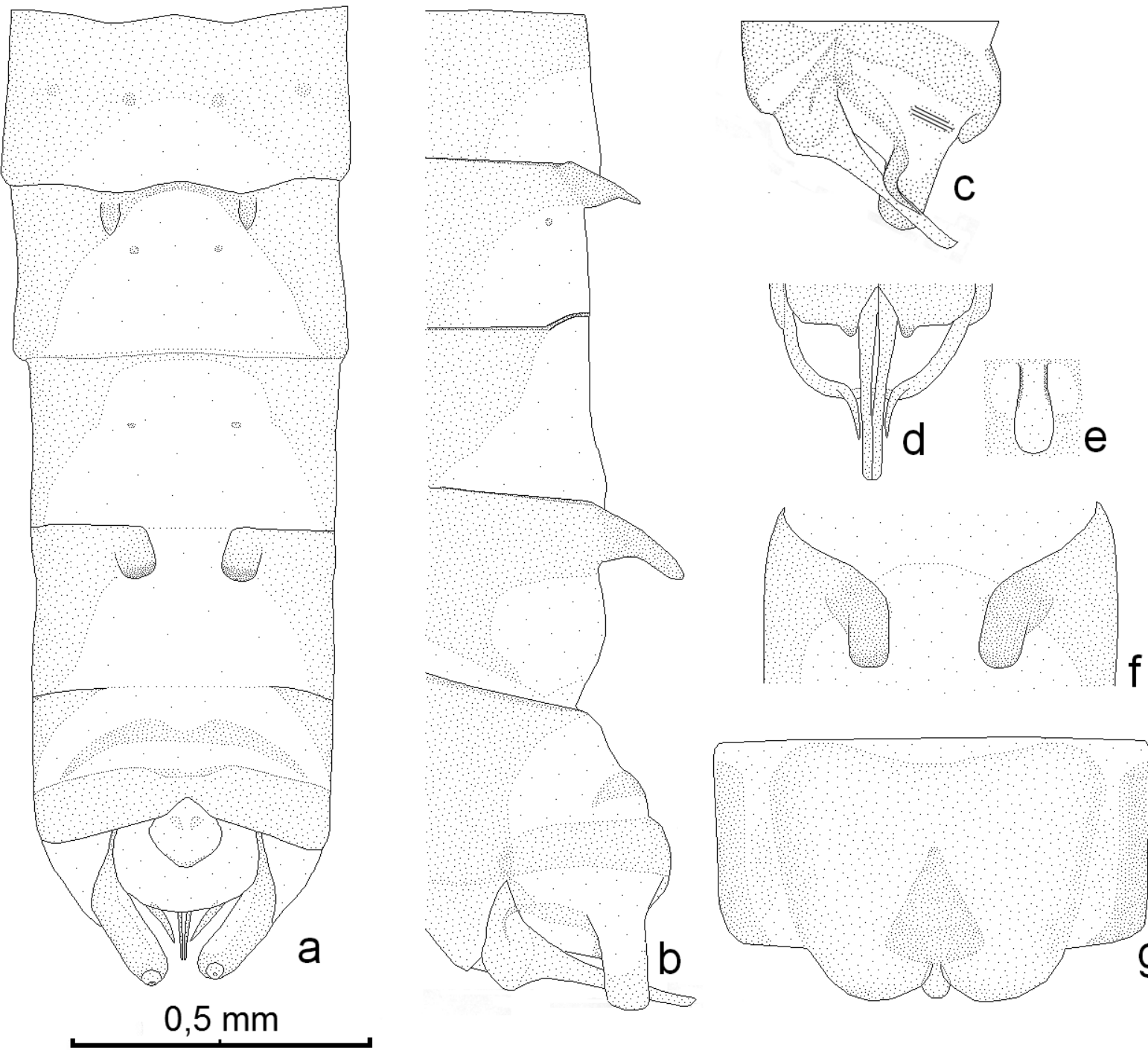

Figure 2. Leuctra nigra, from France, Allevard, Val Pelouse. Male: $\mathbf{a}=$ abdomen tip, dorsal view, $\mathbf{b}=$ lateral view; $\mathbf{c}=$ paraprocts lateral view, $\mathbf{d}=$ ventral view; $\mathbf{e}=$ ventral vesicle; $\mathbf{f}=$ tergite VIII top view. Female: $\mathbf{g}=$ subgenital plate, ventral view.

24.05.1998, 1ㅇ, 19.05.2013, 7ふ, 5ㅇ, 2.06.2013, 2ふ, 1 ㅇ (Vin). SWITZERLAND, JURA MASSIF: NW Tramelan, Gruère Lake, b. right side of the lake, 20.06.2012, 5^, $11 q$ (Vin). GERMANY: Fulda, 1981, 2ô, $1 \uparrow$ (Zwick leg), SLOVAKIA: Vysoké Mountains, Tatry, Podspady, Javorinka r., 11.07.1967, 5ð̂, 5 ㅇ (Steinmann \& Mur).

Complementary description. Based on French specimens: Savoie, Allevard, Val Pelouse, 1400 m, 7.06.1987. Male (Fig. 2a-f): Tergite VI with two small triangular appendices pointing upwards and backwards in side view (Fig. 2b). Tergite VII with non-interrupted anterior margin and wide median bell-shaped membranous area. Tergite VIII with two strong teeth pointing upwards and backwards in side view (Fig. 2a, b, f); teeth sub-rectangular in dorsal view (Fig. 2f). Tergite IX with anterior margin interrupted on nearly half segment width, lateral edges triangular ending in sharp angles near anterior margin. Lateral lobes of paraprocts with a sclerotized hook-shaped expansion turning backwards and extending along distal part of specilla (Fig. 2c-d). Specilla straight in ventral and side views (Fig. 2c-d), slightly curved at their tip (Fig. 2c). Sternite IX: ventral vesicle racket-shaped (Fig. 2e). Female (Fig. $2 \mathrm{~g}$ ): subgenital plate with two rounded lobes separated by a small rounded lamella; a triangular sclerite placed between the 2 lobes is visible beneath transparent cuticle.

\section{Leuctra biellensis Festa, 1942}

Figs 1, 3a-g, 4

\section{Leuctra biellensis, Consiglio 1962}

Leuctra nigra Oliv., Fochetti and Tierno de Figueroa 2008: 259, fig. $160 \mathrm{a}-\mathrm{f}$.

Locus typicus: Alpe Finestre, Val Chiobbia, Piemonte (altitude 1700 m).

Material examined. Neotype (GBIFCH00235761): Italy, Pennine Alps : Biellese mountains, Oropa, torrents and brooks, 1200-1900 m, 06.1978-07.1978, Coll. C. 

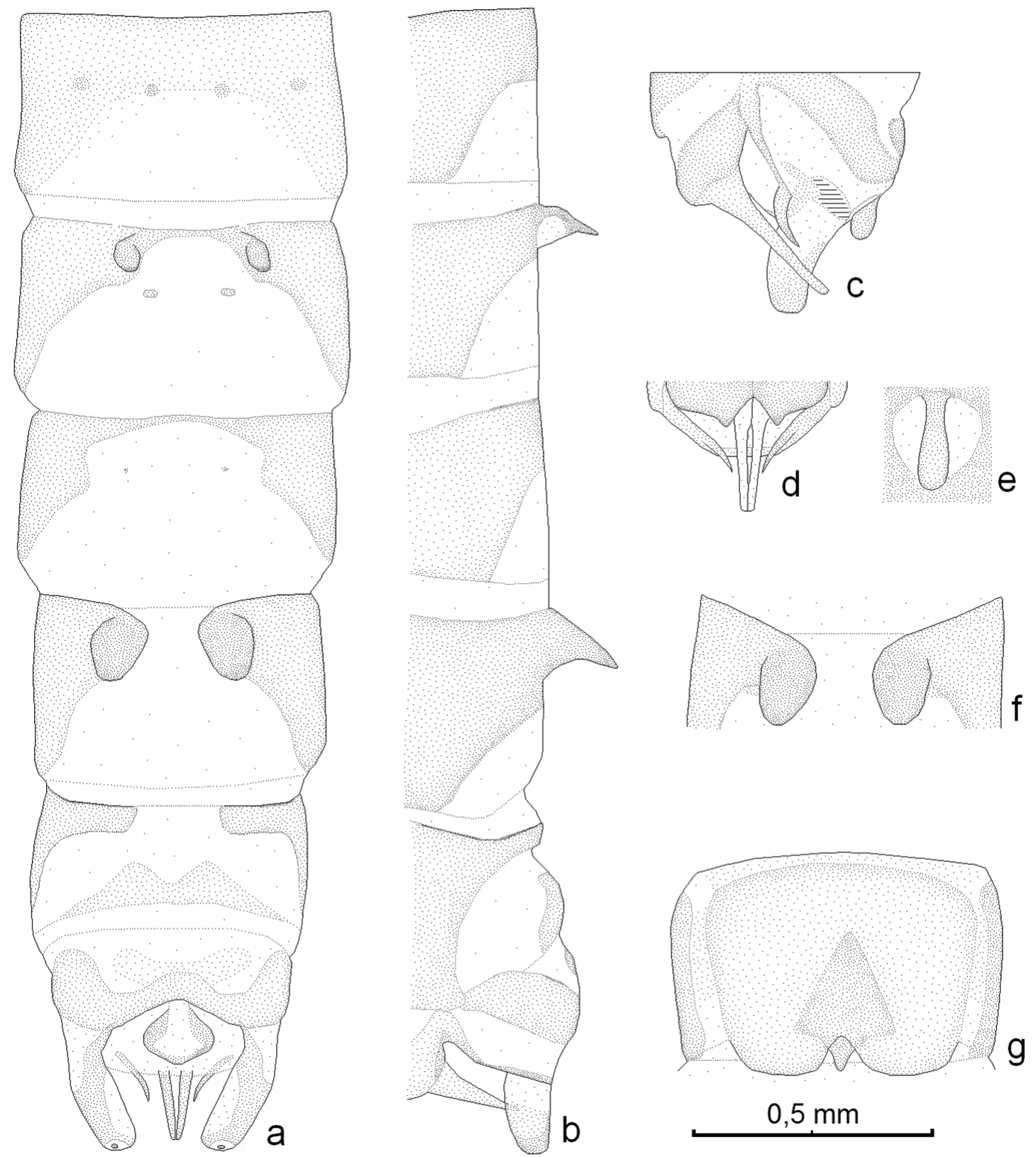

Figure 3. Leuctra biellensis from Swiss, Ceneri Mount, Isone. Male: $\mathrm{a}=$ abdomen tip, dorsal view, $\mathrm{b}=$ lateral view; $\mathrm{c}=$ paraprocts lateral view, $\mathbf{d}=$ ventral view; $\mathbf{e}=$ ventral vesicle; $\mathbf{f}=$ tergite VIII top view. Female: $\mathbf{g}=$ subgenital plate, ventral view.

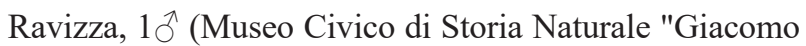
Doria", Genova, Italy).

Topotypes (GBIFCH00235762): same data as neotype: $175 \hat{\jmath}, 153$.

ITALY: Pennine Alps: Civiasco, (NO), $700 \mathrm{~m}$,

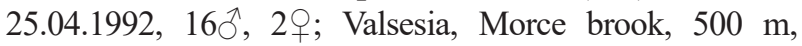
25.04.1975, $5 \hat{\jmath}, 1$ q (Rav); Biellese mountains, brooks, Elvo trib., 1100 m, 18.05.1981, 7ð, 19 (Rav); Biellese mountains, Donato, Vione tor., 950 m, 21.05.1979, 16 larves (1 male nymph) (Rav); Andrate, Graglia, slow brook, Mombarone mount, 5.06.1978, ふૈ, ㅇ (Rav). Aosta Valley, Dora Baltea trib., > Trovinasse, Colla della Lace, 1900 m, 11.07.2003, 1今̄; > Trovinasse, Colla della Lace, 1700 m, 24.05.2003, 4ก̂, 6ㅇ; Dora Baltea trib., Pont-St-Martin, > Carema, 500 m, 1.06.1991, 2犬̂, 4우 Dora Baltea trib., > Nomaglio, road from Andrate to Biella, $600 \mathrm{~m}, 1.06 .1991,13 \hat{\jmath}, 9 \bigcirc$; 31.03.2000, 1ठ, 1울. E. Varallo, Civiasco, Sesia trib., b., 850 m, 2.06.1991, 2ð, 1q; N. Varallo, > Cervarolo, 1500 m, 2.06.1991, 4ðे, 1우 < Cervarolo, > Piane del Alpe, b., 1200 m, 2.06.1991, 9ð̄, 6; W. Grevellona, Val Strona, $>$ Campello Monti, 1500 m, 13.08.2005, 19; Val Strona, $>$ Massiola, < Rosarolo, b., 750 m, 26.04.1999, 12ર̂, 3 우 Val Strona, > Omegna, b., 500 m, 24.05.2003, 2ð, 1 ; SW. Domodossola, Valle Anzasca, Macugnaga, Staffa, b., 1300 m, 2.06.1991, 16त, 16웅 Valle Anzasca, Macugnaga, Prequartera, $800 \mathrm{~m}, 1.06 .1991,3 \hat{\jmath}, 3 \uparrow$ (Vin). Cottian Alps:

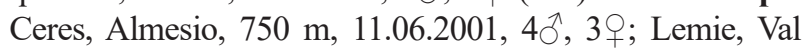
d'Ovarda, A. Milone, 1650 m, 20.06.2001, 1今̄, 4ㅇ; Locana, 


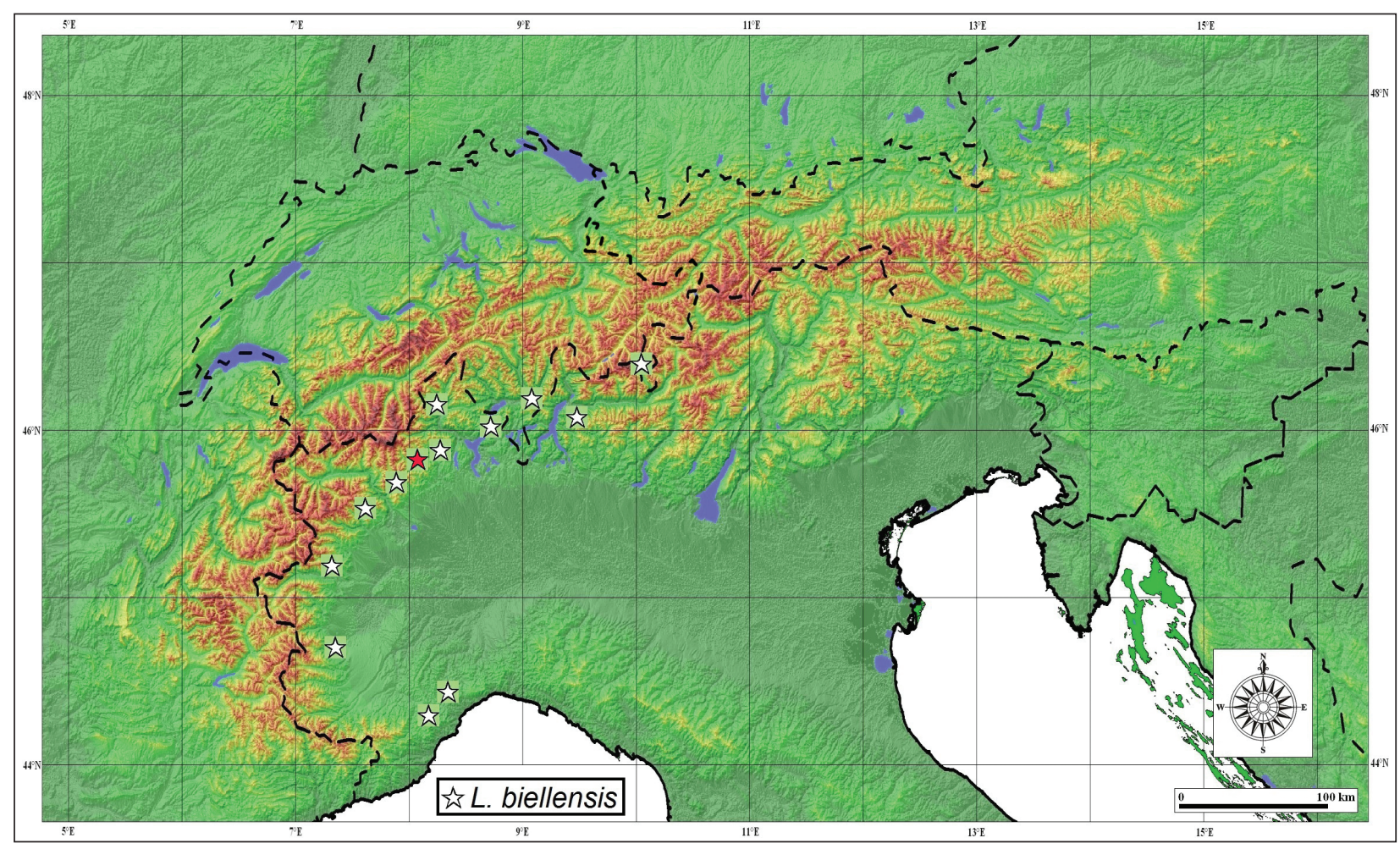

Figure 4. Distribution area of Leuctra biellensis. Red star = Type locality. White star = other localities with L. biellensis.

val Piantonetto, S. Giacomo, 1130 m, 26.06.2001, 1우 Villafranca Piemonte, TO, Cappella della Missione, $260 \mathrm{~m}$, 24.03.2002, 2 ${ }^{\lambda}$; (Del); Graian Alps: Frassinato brook, Soana trib., $1000 \mathrm{~m}, 18.06 .1992,1$ ( (Rav); Val Soana, 700 - 850 m, 11 $\hat{\jmath}, 6$ ㅇ (Rav); Lis Pass, > Girardi, Stura di Lanza trib., b., 1100 m, 7.05.2000, 5ô, 2ᄋ; 27.08.2005, 2q; Val di Viu, Stura di Lanza trib., > Viu, Piazette, b., 1200 m, 1.04.2000, 3今ं; Val di Viu, Stura di Lanza trib., < Viu, brook, 600 m, 22.04.2008, 3今े, 6; NE. Lanzo Torinese, > Corio, Pian d'Audi, Rio Malone trib., 865 m, 23.10.2000, 1; Aosta Valley, > Quincinetto, > Scalaro, 1500 m, 1.05.2009, 1q; $>$ Quincinetto, Rio della Folla, 1250 m, 11.07.2012, 1q; > Quincinetto, road to Lecchia sup. and road to Scalaro (iron bridge), 1100 m, 1.05.2009, 1§; Aosta Valley, > Champorcher, Valle della Legne, Ayasse trib., 1200 m, 6.05.2000,

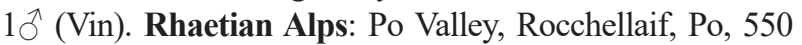
m, 1.05.1982, 4ð̂, 1 + (Rav). Liguria: Calizzano brook, 900 m, 28.04.1976, $3 \widehat{\jmath}$ (Rav); (SV) Calizzano, Melogno Pass,

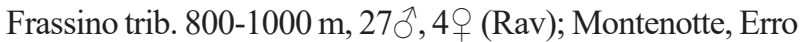
spring, 700-950 m, 4.05.1974, 48 $\hat{\jmath}, 40 \bigcirc+65 \hat{\jmath}, 58$ (Rav); Mont San Giorgio, brook, 750 m, 16.04.1974, 10ふै, 3 ㅇ (Rav). Lombardia, Casargo, (CO), Varonne tor., 2.06.1973,

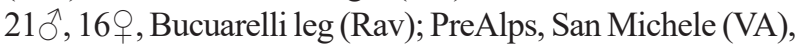
Olocrene spring, $800 \mathrm{~m}, 8.07 .1986,2 \hat{\jmath}, 3$ +(Rav).

SWITZERLAND: Ticino, Lepontine Alps: Ceneri Mount, $>$ Isone, before the military base, 1.04.2015, 10 $\hat{\jmath}, 5$ + (Vin); Valle Lucoresagguo, Piace Seguo, 1650 m, 23.05.1988, $28 \hat{\jmath}, 16 \circ$ (Rav). Rhaetian Alps: Graubünden, Cavagliasch, Cavaglia, 1690 m, 30.05.2007, $2 \lesssim$ (P. Baumann).

Complementary description. Male (Fig. 3a-f): Tergite VI with two small triangular appendices pointing upwards and backwards in side view (Fig. 3b). Tergite VII with non-interrupted anterior margin and wide median bellshaped membranous area. Tergite VIII with two strong teeth pointing upwards and backwards (Fig. 3a, b) and nearly triangular in dorsal view (Fig. 3f). Tergite IX with anterior margin interrupted on nearly one third of segment width, lateral edges sub-triangular forming a wide strip along anterior margin (Fig. 3a). Lateral lobes of paraprocts with a sclerotized sickle-shaped expansion slightly bent towards distal part of specilla (Fig. 3c-d). Specilla straight in ventral and side views (Fig. 3c-d). Sternite IX: ventral vesicle racket-shaped (Fig. 3e). Female (Fig. 3g): subgenital plate with two rounded lobes separated by a small triangular lamella; a triangular sclerite placed between the 2 lobes is visible by transparency under the cuticle.

Ecological preferences and distribution area. Leuctra biellensis is a crenophilic species occurring in springs and brooklets at various altitudes $(260-1900 \mathrm{~m})$. The flight period is mainly in spring and early summer (III-VII) but few adults also occur in autumn (VIII-X). Its distribution area widely covers the western part of the Italian Alps from the Rhaetian Alps to the Maritime Alps and also extends in Liguria (Fig. 4). Its occurrence in Switzerland is restricted to the southern slope of the Alps.

\section{Discussion}

Aubert (1954) was the first who challenged the validity of Leuctra biellensis, suggesting that it could be a junior synonym of Leuctra nigra, but without formally establishing 
the synonymy. In the same way, Illies (1966) also considered the species as doubtful but did not change its status. Consiglio $(1962,1967)$ likewise adopted an ambivalent attitude. He first considered $L$. biellensis to be a valid species (Consiglio 1962), then changed his mind and established the synonymy with L. nigra (Consiglio 1967, p. 18). This synonymy was then confirmed by Zwick (1973). However, neither Aubert nor Consiglio adduced the required morphological details that would have justified this synonymy.

Male and female imagos of these two species can be morphologically distinguished by the following characters. In the male, the two teeth of tergite VIII are sub-triangular in dorsal view in L. biellensis (Fig. 3f), instead of sub-rectangular in L. nigra (Fig. 2f); the lateral edges of tergite IX form a wide sclerotized strip on nearly half part of the anterior margin in L. biellensis (Fig. 3a), while they end in acute angles in L. nigra (Fig. 2a); the distal expansions of the paraprocts are sickle-shaped and not lying along the specilla in L. biellensis (Fig. 3d), while they are hook-shaped with their tip lying along the specilla in L. nigra (Fig. 2d). In the female, the lamella between the two lobes of the subgenital plate is triangular in L. biellensis (Fig. 3g) and rounded in L. nigra (Fig. 2g).

Leuctra biellensis is an alpine micro-endemic species only occurring in the western and internal part of the Alps like other cryptic species of Plecoptera (Ravizza and Vinçon 1998) or Trichoptera (Graf et al. 2015). The species is strongly crenophilic, with long flight period (III-X). Conversely, L. nigra is a central north-European species, mainly occurring in lentic biotopes and with shorter flight period (V-VIII) (Ravizza and Vinçon 1998). Both species were never collected together in the same locations and therefore $L$. biellensis can be considered as a sister species of $L$. nigra, inhabiting the internal slope of the Alps where it was probably isolated from L. nigra. The same applies to many other alpine species such as $L$. muranyii Vinçon and Graf, 2011 and L. juliettae Vinçon and Graf, 2011, two sister species of $L$. braueri Kempnyi, 1898, isolated in a restricted part of the eastern Alps (Vinçon and Graf 2011). Molecular tools associated with morphological characters are very promising to separate species in groups with recent diversification (Vitecek et al. 2017).

We found around $9 \%$ of distance between COI haplotypes of L. nigra and L. biellensis. While a 3.5\% COI sequence distance has been proposed in the DNA barcoding literature as a likely maximal value for intraspecific divergence (Hebert et al. 2003; Zhou et al. 2010), higher intraspecific K2P and $p$ values are not uncommon (e.g., Meier et al. 2006), and have also been reported for Plecoptera (Mynott et al. 2011; Boumans and Baumann 2012; Gill et al. 2015). Nonetheless, 9\% distance is an unlikely intraspecific value. We are aware that species cannot be identified or described based on mitochondrial sequences alone. A major reason for this is that strongly divergent haploclades in some populations may result from hybridisation and subsequent mitochondrial introgression (Boumans and Tierno de Figueroa 2016). For this reason, we emphasise that the mitochondrial and morphological data converge to identify L. biellensis as a valid species distinct from L. nigra. Since our molecular study also contains Scandinavian samples, our results confirm the presence of L. nigra in this area and tend to confirm the synonymy made by Brinck (1949) of Leuctra acuminata Bengtsson, 1933 with L. nigra, especially as $L$. acuminata was established for specimens from Sweden originally identified as $L$. nigra.

\section{Acknowledgements}

We express our gratitude to Giovanni Delmastro (Carmagnola, Italy), Jean-Paul Reding (Neuchâtel, Switzerland) and Dávid Murányi (Budapest, Hungary) for their help and donation of comparative material, to J. Manuel Tierno de Figueroa (Granada, Spain), Wolfram Graf (Wien, Austria), Jean-Paul Reding for reviewing the manuscript. We also want to thank Sofia Wyler (SwissBOL), Albertine Roulet, Marion Podolak and Nicolas Hazi (MZL) for preparing the specimens stored in the MZL collection and sequencing them. We want to thank Lars Hendrich for giving us access to molecular data from the Project "Fauna Bavaria Barcoding" managed by the Zoologische Staatssammlung, München, Germany and Maria Tavano (Museo Civico di Storia Naturale "Giacomo Doria", Genova, Italy) for hunting for the type material of Leuctra biellensis.

\section{References}

Aubert J (1954) Contribution à l'étude du genre Leuctra Stephens et description de quelques espèces nouvelles de ce genre. Mitteilungen der Schweizerischen Entomologischen Gesellschaft 27: 124-136.

Aubert J (1959) Plecoptera. Insecta Helvetica (1). Société Entomologique Suisse, Lausanne, 140 pp.

Bengtsson S (1933) Plecopterologische studien. Lund universitets Årsskrift 29: 1-50.

Boumans L, Baumann RW (2012) Amphinemura palmeni is a valid Holarctic stonefly species (Plecoptera: Nemouridae). Zootaxa 3537(1): 59-75.

Boumans L, Brittain JE (2012) Faunistics of stoneflies (Plecoptera) in Finnmark, northern Norway, including DNA barcoding of Nemouridae. Norwegian Journal of Entomology 59: 196-215.

Boumans L, Tierno de Fiqueroa JM (2016) Introgression and species demarcation in western European Leuctra fusca (L., 1758) and $L$. digitata Kempny, 1899 (Plecoptera, Leuctridae). Aquatic Insects 37(2): 115-126. https://doi.org/10.1080/01650424.2016.1161200

Brinck P (1949) Studies on Swedish stoneflies (Plecoptera). Opuscula Entomologica, supplement 11: 1-250.

Consiglio C (1962) Contributo alla conoscenza dei Plecotteri del Piemonte, Valle d'Aosta e Liguria. Memorie della Società Entomologica Italiana 41: 25-44.

Consiglio C (1967) Lista dei Plecotteri della regione italiana. Fragmenta Entomologica 5(1): 1-66.

Conti L, Schmidt-Kloiber A, Grenouillet G, Graf W (2014) A traitbased approach to assess the vulnerability of European aquatic insects to climate change. Hydrobiologia 721: 297-315. https://doi. org/10.1007/s10750-013-1690-7 
Despax R (1951) Plécoptères - Faune de France (55). Paris, 280 pp.

Errochdi S, Vinçon G, El Alami M (2014) Contribution to the knowledge of the Rifan stoneflies (Morocco). Mitteilungen der Schweizerischen Entomologischen Gesellschaft 87: 25-40.

Festa A (1942) Plecotteri raccolti dal Dott. Felice Capra in Val Chiobbia. Bollettino della Società Entomologica Italiana 74: 61-63.

Fochetti R, Tierno de Figueroa JM (2008) Fauna d'Italia Vol. XLIII. Plecoptera. Ministero dell' Ambiante e della Tutela del Territorio, Direzione per la protezione della Natura. Calderini, 339 pp.

Gattolliat JL, Vinçon G, Caetano Wyler SA, Pawlowski J, Sartori M (2016) Towards a comprehensive barcode library for Swiss Stoneflies. Zoosymposia 11: 135-155. https://doi.org/10.11646/zoosymposia.11.1.15

Geiger MF, Moriniere J, Hausmann A, Haszprunar G, Wägele W, Hebert PD, Rulik B (2016) Testing the Global Malaise Trap Program - How well does the current barcode reference library identify flying insects in Germany? Biodiversity Data Journal 4: e10671. https:// doi.org/10.3897/BDJ.4.e10671

Gill BA, Sandberg JB, Kondratieff BC (2015) Evaluation of the morphological species concepts of 16 western Nearctic Isoperla species (Plecoptera: Perlodidae) and their respective species groups using DNA barcoding. Illiesia 11(11): 130-146.

Graf W, Vitecek S, Previšić A, Malicky H (2015) New species of Limnephilidae (Insecta: Trichoptera) from Europe: Alps and Pyrenees as harbours of unknown biodiversity. Zootaxa 3911(3): 381-395. https://doi.org/10.11646/zootaxa.3911.3.5

Hebert PDN, Cywinska A, Ball SL, DeWaard JR (2003) Biological identifications through DNA barcodes. Proceedings of The Royal Society B - Biological Sciences 270: 313-321. https://doi. org/10.1098/rspb.2002.2218

Hendrich L, Balke M, Haszprunar G, Hausmann A, Hebert P, Schmidt S (2010) Barcoding Fauna Bavarica - Capturing Central European Animal Diversity. In: Nimis PL, Vignes Lebbe R (Eds) Tools for Identifying Biodiversity: Progress and Problems. Paris, 347 pp.

Illies J (1955) Steinfliegen order Plecoptera. Die Tierwelt Deutschlands 43: $1-150$.

Illies J (1966) Katalog der rezenten Plecoptera. Das Tierreich 81(I-IXXX): 1-632.

International Commission on Zoological Nomenclature (1999) International code of Zoological Nomenclature. Fourth Edition. The International Trust for Zoological Nomenclature, London, 306 pp.

Kempny P (1898) Zur Kenntniss der Plecopteren. II. Neue und ungenügend bekannte Leuctra-Arten. I Theil. Verhandlungen der Zoologisch-Botanischen Gesellschaft in Wien 48: 213-221.

Kis B (1974) Insecta. Plecoptera. Fauna Republicii Socialiste România, Vol. 8, fasc. 7. Academiei Republicii Socialiste România, Bucarest, $271 \mathrm{pp}$.

Kühtreiber J (1934) Die Plekopterenfauna Nordtirols. Berichten des Naturwissenschaftlich-Medizinischen Vereines in Innsbruck 43/44(VIII): 1-219.

Kumar S, Stecher G, Tamura K (2016) MEGA7: Molecular Evolutionary Genetics Analysis version 7.0 for bigger datasets. Molecular Biology and Evolution 33: 1870-1874. https://doi.org/10.1093/molbev/ msw054

Lubini V, Knispel S, Vinçon G (2012) Les Plécoptères de Suisse. Identification et distribution. Fauna Helvetica (27), CSCF and SEG publishers, Neuchâtel, 270 pp.

Meier R, Shiyang K, Vaidya G, Ng PK (2006) DNA barcoding and taxonomy in Diptera: a tale of high intraspecific variability and low identification success. Systematic Biology 55(5): 715-728. https:// doi.org/10.1080/10635150600969864

Mendl H (1968) Steinfliegen aus Bayern neu für Deutschland (Insecta Plecoptera). Bayerische Tierwelt 1: 97-114.

Mosely ME (1932) A revision of the European species of the genus Leuctra. Annals and Magazine of Natural History 10(X): 1-41. https://doi.org/10.1080/00222933208673537

Mynott JH, Webb JM, Suter PJ (2011) Adult and larval associations of the alpine stonefly genus Riekoperla McLellan (Plecoptera : Gripopterygidae) using mitochondrial DNA. Invertebrate Systematics 25: 11-21. https://doi.org/10.1071/IS10025

Olivier G (1811) Némoure in Encyclopédie méthodique. Histoire naturelle, Insectes 8: 184-186.

Ravizza C, Vinçon G (1998) Les Leuctridés (Plecoptera, Leuctridae) des Alpes. Mitteilungen der Schweizerischen Entomologischen Gesellschaft 71: 285-342.

Srivathsan A, Meier R (2012) On the inappropriate use of Kimura-2-parameter (K2P) divergences in the DNA-barcoding literature. Cladistics 28: 190-194. https://doi.org/10.1111/j.1096-0031.2011.00370.x

Tamura K, Nei M (1993) Estimation of the number of nucleotide substitutions in the control region of mitochondrial DNA in humans and chimpanzees. Molecular Biology and Evolution 10: 512-526.

Teslenko VA, Zhiltzova LA (2009) Key to the stoneflies (Insecta, Plecoptera) of Russia and adjacent countries. Imagines and nymphs. Institute of Biology and Soil Science, Far Eastern Branch of Russian Academy of Sciences. Dalnauka, Vladivostok, 382 pp.

Tierno de Figueroa JM, López-Rodríguez MJ, Lorenz A, Graf W, Schmidt-Kloiber A, Hering D (2010) Vulnerable taxa of European Plecoptera (Insecta) in the context of climate change. Biodiversity and Conservation 19: 1269-1277. https://doi.org/10.1007/s10531009-9753-9

Vinçon G, Graf W (2011) Two new Alpine Leuctra in the L. braueri species group (Plecoptera, Leuctridae). Illiesia 7(09): 92-103.

Vitecek S, Vinçon G, Graf W, Pauls SU (2017) High cryptic diversity in aquatic insects: an integrative approach to study the enigmatic Leuctra inermis species group (Plecoptera). Arthropod Systematics and Phylogeny 75(3): 497-521.

Zhou X, Jacobus LM, DeWalt RE, Adamowicz SJ, Hebert PDN (2010) Ephemeroptera, Plecoptera, and Trichoptera fauna of Churchill (Manitoba, Canada): insights into biodiversity patterns from DNA barcoding. Journal of the North American Benthological Society 29: 814-837. https://doi.org/10.1899/09-121.1

Zwick P (1973) Insecta: Plecoptera Phylogenetisches System und Katalog. Das Tierreich 94(IXXXII): 1-465. 